\title{
Yield, nutrient and water use efficiency and economics of maize as influenced by levels of irrigation and fertigation
}

\section{J. S. VENKATA SHIVA REDDY AND R. KRISHNA MURTHY}

Received : 22.02.2017; Revised : 10.05.2017; Accepted : 22.05.2017

MEMBERS OF RESEARCH FORUM:

Corresponding author : J. S. VENKATA SHIVA REDDY, Department of Soil Science and Agricultural Chemistry, AICRP on Dryland Agriculture, University of Agricultural Sciences G.K.V.K., BENGALURU (KARNATAKA) INDIA Email: srkmurthyssac@gmail.com

Co-authors : R. KRISHNA MURTHY, Department of Soil Science and Agricultural Chemistry, AICRP on Dryland Agriculture, University of Agricultural Sciences G.K.V.K., BENGALURU (KARNATAKA) INDIA Email: srkmurthyssac@gmail.com

\section{Summary}

A field experiment was conducted during Kharif 2015 at Zonal Agricultural Research Station, V.C. Farm, Mandya, Southern Dry Zone of Karnataka to study the growth and yield of maize as influenced by drip fertigation. The experiment was laid out in Randomized Complete Block Design with three replications and eleven treatments comprising two levels of irrigation and four levels of fertilizers, absolute control, package of practice and paired row of spacing $45 \mathrm{x}$ $75 \mathrm{~cm}$. Irrigation @ 100\% cumulative pan evaporation + drip fertigation 125\% recommended dose fertilizer was found higher kernel yield $\left(7763 \mathrm{~kg} \mathrm{ha}^{-1}\right)$ and stover yield $\left(8159 \mathrm{~kg} \mathrm{ha}^{-1}\right)$. Higher nitrogen, phosphorus and potassium use efficiency was recorded in irrigation @ $100 \%$ cumulative pan evaporation + drip fertigation $75 \%$ recommended dose fertilizer $(65,131$ and $245 \mathrm{~kg} \mathrm{~kg}^{-1}$, respectively). Significantly higher water use efficiency was found in irrigation @ 75\% cumulative pan evaporation+ drip fertigation 125\% recommended dose of fertilizer $\left(132.17 \mathrm{~kg} \mathrm{ha} \mathrm{cm}^{-1}\right)$ over University of Agricultural Sciences- package $\left(74.18 \mathrm{~kg} \mathrm{ha} \mathrm{cm}{ }^{-1}\right)$. Higher cost of cultivation was recorded in irrigation @ 100\% cumulative pan evaporation + drip fertigation $125 \%$ recommended doses fertilizer (Rs.37089 ha-1) followed by irrigation @ 100\% cumulative pan evaporation + drip fertigation 100\% recommended dose fertilizer (Rs. 35379 ha $\left.^{-1}\right)$.

Key words : Drip fertigation, Water use efficiency, Nutrient use efficiency

How to cite this article : Reddy, J. S.Venkata Shiva and Murthy, R.Krishna (2017). Yield, nutrient and water use efficiency and economics of maize as influenced by levels of irrigation and fertigation. Asian J. Soil Sci., 12 (1) : 181-186 : DOI : 10.15740/HAS/AJSS/12.1/181-186. 